\title{
The Translation of Religious Words and Expressions in Naguib Mahfouz's Sugar
}

\author{
Ahmed Sokarno Abdel-Hafix \\ Dept. of English, Faculty of Arts \\ Aswan University, Egypt \\ Sokarno2001@hotmail.com
}

\begin{abstract}
Different translators employ different strategies in translation. The translation of culture-specific elements is particularly challenging to translators. Some translators prefer a domesticating strategy, which is characterized by the replacement of foreign cultural elements with TL ones. Other translators opt for a foreignizing strategy, which enables the translator to preserve the values of SL culture. It is true that globalization has turned our universe into a small village where people have become more and more familiar with the cultures of other people. Thus peoples of different countries may share most of the cultural elements: food, clothing, sports, entertainment etc. Only religion remains resistant to change. Religion is one of the three axes that Mahfouz's novels revolve around. This study aims at identifying the strategies the translators of Naguib Mahfouz's Sugar Street have employed in rendering religious words and religious expressions. This requires examining both the source text and the target text. Having identified the religious words and expressions in the novel, I traced them in the translated text. It turned out that the translators have used three major types of strategies: foreignizing strategy, domesticating strategy, and a mixture of these two. However, the investigation of these strategies has shown that the foreignizing strategy is the most frequent in the translation of this novel.
\end{abstract}

Key words: Mahfouz, domestication, foreignization, cultural items, religious expressions

\section{Introduction}

Most Muslims consider religion to be an important part of their life. Their everyday conversation is often characterized by religious words and expressions. Most of their customs and social life (e.g. marriage, birth, death etc.) revolve around religion. Therefore, we are not surprised when we find that religion is one of three axes around which Mahfouz's works revolve, the other two being sex and politics (cf. El-Enany 1988, p.7). Mahfouz's novels, specially social novels, deal with various social and political issues in the Egyptian society. Therefore, culturespecific items relating to religion, politics, customs, food and drinks permeate these novels. More specifically, religion is often present in the life of Mahfouz's characters, who do not hesitate to use religious words and expressions in their conversation.

We need to clarify what is meant by religious words and expressions. Word is defined as "the smallest unit in language that can be used by itself" (Bolinger and Sears 1968, p. 43). As for the written word, it is characterized as "any sequence of letters with an orthographic space on either side" (Baker 1992, p.11). Religious words in the original novel often refer to the Islamic world such as 'Ramadan', asr prayer, hajj, zakaat etc. As Baker (1992) explains, the word in the source language (SL) "may express a concept which is totally unknown in the target culture ....The concept may relate to a religious belief, a social custom, or even a type of food. Such concepts are often referred to as culture-specific.". (p. 21) By religious expressions, I mean the Arabic expressions that refer to the Islamic world and are used frequently by Muslims in everyday conversation. As Washbourne and Nyke (2018) put it, "Arabic language users are used to these religious expressions in their daily talk". This paper aims at investigating how such religious words and expressions are rendered in the translation of Naguib Mahfouz's Sugar Street, which is the last volume of The Cairo Trilogy, the other two being Palace Walk and Palace of Desire.

\section{The Purpose of the Study}

Translating religious words and expressions is one of the greatest challenges faced by translators. Translators differ as to the appropriate strategies to be employed in such situations. This study aims at figuring out how the translators (i.e. William Maynard Hutchins and Angele Botros Samaan) of Naguib Mahfouz's Sugar Street have dealt with religious words and expressions and what strategies they have used in order to overcome the problem of translating them. The ultimate goal of this study is to determine whether the translators have relied on foreignizing or domesticating strategies. Thus an attempt is made to anwer the following Questions:

1. What are the strategies used by the translators of the novel for dealing with the religious words and expressions?

2. Which strategy is most frequently employed in the translation?

3. Is there any difference in the choice of strategies when dealing with religious words and religious expressions?

4. Have the translators succeeded in foreignizing or domesticating the translated text? 


\section{The Significance of this Study}

The significance of this study is not difficult to point out. First, Naguib Mahfouz is a Noble-Laureate whose novels have been translated into several languages. Therefore, it is essential that these translations are rendered as accurately as possible. Second, translation plays a pivotal role in introducing Islamic culture to other cultures; it can close the gap between cultures. Any failure to introduce cultural elements in general and religious ones in particular, is considered an additional impediment to mutual understanding and respect among people of different countries. Finally, if we draw the attention of translators to these facts, they will be more careful in dealing with religion-specific items or expressions.

\section{Previous Studies}

There are several studies that have dealt with culture-specific items. It is proven that most translators of literary works do not feel comfortable with the idea of dealing with such culturally-loaded items. Khammyseh (2015) has argued that the translation of Islamic expressions (e.g. expressions relating to marriage occasion) pose a host of problems to translators. According to Khammyseh (2015, p. 105), "most of the translators indicated that cultural voids, equivalence and languages styles were most of the problems and difficulties that faced them when they attempted to translate Islamic expression."

Studies have also proven that translators differ as to the appropriate strategies that can deal with cuture-specific items or elements. Drawing from a corpus of six Arabic novels, Aldebyan (2008) tackles the problem of translating cultural markers from Arabic into English. These markers cause a lot of headache to translators because more often than not they do not have equivalents in the target language (TL). According to Aldebyan (2008, iii), the most successful translations "are the ones that employ foreignizing translation strategies.". In contrast, Baawaidhan (2016) has studied Watson's translation of "Musid wa Musida " with the purpose of determining how the translator has "overcome the linguistic and cultural barriers in translating dialectical expressions and cultural norms."(p. 198). As Baawaidhan (2016, p.206) has put it, "Regarding the religious texts, it is clear that Watson has employed the domestication strategy in rendering both the fixed religious references and the cultured expressions", for example, the translator has rendered the religious expression لا حوال و لا قوة إلا بالله as “that's fair" (p. 206).

Even the studies that have handled the translations of Mahfouz's novels have referred to the difficulty of dealing with cultural markers. Abdel-Hafiz (2004) has shown that the translators of Mahfouz's novels, The Beginning and the End and The Palace of Desire have failed to fully utilize the strategies (e.g. paraphrasing, transliteration, annotation, etc.) that are available for coping with the cultural elementswhich permeate these novels. These cultural elements fall into different categories: religion, politics, food, music etc. Some of these culture-bound items resist translation and need special attention.

Likewise, Mehawesh and Sadeq (2014) have investigated the challenges involved in translating Islamic religious expressions in the Naguib Mahfouz's novel The Beginning and the End. They attempted to identify the strategies (paraphrasing, transliteration, annotation, etc) the translator of this novel used in "translating and handling problems involved in conveying religious associations from Arabic into English." (p.7). Shehab (2005) has investigated the problem of translating five terms of address (social honorifics) in Mahfouz's novel Ziqaq-AlMidaq. He has argued that "relational terms of address are harder to translate than absolute ones due to the fact that relational honorifics have drifted extensively from their traditional usages and acquired new significations which are initiated for social purposes." (p.309). Similarly, Al Rabadi (2012) has studied the way proper names are translated in Naguib Mahfouz's The Cairo Trilogy. She has shown that the foreignizing strategy used by the translators in rendering the proper names is not appropriate for it has resulted in the loss of the folkloric touch that characterizes Mahfouz's style. She attributes this failure on the part of translators to "the linguistic and cultural gaps between the source language and the target one" (Al Rabadi 2012, p. 43). Obeidat and Mahadi (2019) have studied collocation translation errors in the translation of Naguib Mahfouz's Awlad Haratina. They object to the exclusive use of the substitution strategy in rendering collocations. As they put it, "[t]he discussion reveals that collocation should not be translated by only substituting words from ST into TT." (p. 137). They go on to argue that" "the tension between naturalness and accuracy and the cultural- specific collocations in the ST play the vital role in committing translation errors in translating collocations from Arabic into English" (p. 137)As can be seen, these studies have not paid special attention to religious words and expressions. This study is an attempt to fill this gap and to determine the major strategy (i.e. foreignization and domestication) employed by the translators, one of them being a native speaker of the source language, the other a native speaker of the target language.

\section{An Overview of Translation Strategies:}

\subsection{Foreignization and Domestication}

These strategies were first introduced by the German theologian and translator Friedrich Schleiermacher in the $19^{\text {th }}$ century (cf. Munday 2001, p.146). Schleiermacher (1813/1992, p. 41-2, cited in Munday 2001, p.28) argues that the translator has to choose one of two paths: 
"Either the translator leaves the writer alone as much as possible and moves the reader toward the writer, or he leaves the reader alone as much as possible and moves the writer toward the reader.". The first choice forces the translator to adopt what Vanuti calls a foreignizing strategy, whereas the second choice drives the translator towards a domesticating strategy. Vanuti $(1995$, p.20) expresses his dissatisfaction with the domesticating strategy because it results in "an ethnocentric reduction of the foreign text to target-language cultural values.". However, Vanuti (1997) advocates the former strategy (foreginzation), which "entails choosing a foreign text and developing a translation method along the lines which are excluded by dominant cultural values in the target language" (p. 242). As Munday (2001, p. 156) puts it, one of the variety of ways that Vanuti's foreignizing and domesticating translation strategies can be investigated is "by comparing ST [source text] and TT [target text] linguistically for signs of foreignizing and domesticating strategies".

\subsection{Other Translation Strategies}

There are many strategies that are proposed for translating culture-specific items: Vinay and Darbelnet (2000 cited in Munday 2001) proposed two general translation strategies: direct translation and oblique translation. Direct translation comprises three procedures and oblique translation comprises four. The three procedures comprised by direct translation are:

1. Borrowing: the SL word is directly transferred to the TL. (p. 85 cited in Munday 2001, p.56)

2. Calque: "the SL expression or structure is transferred in a literal sense" (p.85 cited in Munday 2001, p.56)

3. Literal translation: this is defined as word-for-word translation.

The following four procedures are comprised by oblique translation:

1. Transposition: one part of speech or word class is changed without changing the meaning of the text.

2. Modulation: this involves the changing of SL point of view or perspective

3. Equivalence: the same situation is described by using SL structure.

4. Adaptation: replacing the SL cultural reference which the TL culture does not have with a TL cultural reference.

Baker (1992) has suggested a translation taxonomy that involves six strategies:

1. Translation by a more general word This strategy is considered "one of the commonest strategies for dealing with many types of non-equivalence". (Baker 1992, p. 26).

2. Translation by a more neutral/ less expressive word.

3. Translation by cultural substitution (Vinay and Darbelnet's adaptation) This strategy "involves replacing a culture-specific item or expression with a target language item which does not convey the same propositional meaning but is likely to have a similar impact on the target reader." (Baker 1992, p.31)

4. Translation by paraphrase using a related word .This strategy "tends to be used when the concept expressed by the source item is lexicalized in the target language but in a different form."(Baker 1992, p. 37)

5. Translation by paraphrase using unrelated words. This strategy is appropriate "if the concept expressed by the source item is not lexicalized at all in the target language" ((Baker 1992, p. 38)

1. Translation by omission By using this strategy, a translator can "omit translating a word or expression in some contexts." ((Baker 1992, p. 40)

2. Translation by illustration. This is used if the word lacks an equivalent in the target language refers to a physical entity which can be illustrated. Schaeffer and Weismann (2001) introduce four translation strategies that can deal with culture-specific items (CSI)

1. Loanword (cf. Vinay and Darbelnet's borrowing) appear when a foreign word with spelling, pronunciation and grammatical gender adopted to TL patterns comes to TL.

2. Calque is the literal translation of the CSI

3. Substitution (cf. Baker's translation by substitution and Vinay and Darbelnet's adaptation strategy) appears when a CSI of a SL is substituted by analogous CSI of TL

4. Explanation (cf. Baker's paraphrase strategies) is the translation strategy when a CSI is explained in the TL.

\section{Methodology and data collection}

I started by reading the Arabic novel, Sugar Street, with the purpose of pinpointing the religious words and expressions. These religion-specific words and expressions are easily spotted by any Muslim reader: they relate to the Islamic world and they are often used in religious or non-religious contexts. Furthermore, religious expressions, unlike words, involve several words that are often fixed. Having identified these religious words and expression, I turned to the translated text with the purpose of finding out how these words and expressions are rendered and what strategy is used in translating each of them. Then these strategies are classified and counted in such a way that the most frequent strategy is identified. Also, an attempt is made to discover whether or not the same strategies are employed in the translation of religious words and religious expressions.Furthermore, an attempt is made to determine whether the translators have relied on foreignizing or domesticating strategies. It seems that the translators, Hutchins and Samaan, have relied on the following strategies whenever they encountered culturespecific words or expressions that have no equivalents in the TL: 
1. Borrowing plus explanation The translators use an SL word as it is in the TL, but they provide an explanation for this word.

2. Borrowing without explanation The translators use an SL word without providing an explanation.

3. Borrowing plus substitution The borrowed SL word is accompanied by a TL equivalent

4. Explanation The SL word or expression is explained using TL words or expressions This strategy is similar to Baker's translation by paraphrase.

5. Substitution The SL religious word or expression is replaced with a TL word or expression.

6. Calque The religious SL expression is translated by borrowing a TL expression, but "the translator translates literally each of its elements. The result is either a lexical calque i.e. one which respects the syntactic structure of the target language while introducing a new mode of expression" (Siregar 2016, p. 51)

7. Calque plus explanation This strategy involves calque supplemented with explanation

8. Omission An expression is omitted if the translators consider it ineffectual or harmless to the meaning of the expression.

\section{Translation of religious words and expressions:}

This section is concerned with the translation strategies used in rendering religious words and religious expressions into the target language. Arabic religious words are rendered into English by way of applying five strategies: borrowing plus explanation, borrowing without explanation, borrowing plus substitution, explanation, and substitution:

$$
\text { وترحب بغبطة لا حد لها بزيارة الحسين إذا دعتها جدتها (السكرية، ص 812) }
$$

And welcomed with limitless delight her grandmother's invitations to visit

The mosque of al-Husayn. (Sugar Street, p. 987)

Notice here that the translators have used the Arabic word الحسين, but they explained the word when they added "the mosque of".

$$
\text { خالك كمال من محاسيب الحسين (السكرية، ص 8477 (84t) }
$$

Your uncle Kamal is watched over by al-Husayn (Sugar Street, p.1059)

Again the word "al-Husayn" is used here, but with a different meaning that is not indicated in the source text. Therefore the translators had to explain it when they used the verb phrase "watched over", which means that alHusayn protected uncle Kamal. The examples given above show how translators used the strategy of borrowing plus explanation. In the following examples, the strategy of borrowing without explanation is to be presented:

فبادرت تتحدث عن سيرة سيدى فى رمضان منذ ساعة استيقاظه فى الضحى (السكرية، ص920)

She launched into a description of what my master did during Ramadan from

The time he woke up late in the afternoon. (Sugar Street, p. 1210)

Note that the translators have used a loanword "Ramadan" without any further explanation of the term.

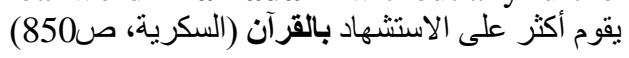

Most of his remarks centered on quotations from the Qur'an. (Sugar Street, p. 1065)

The word "Qur'an" is used here without any additional information.

The following examples show how borrowing can combine with substitution in the translation of religious words:

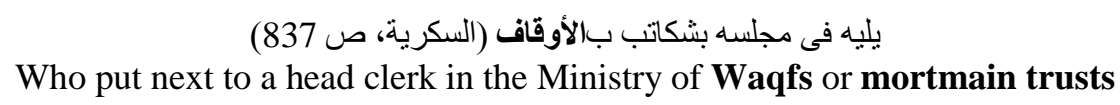

(Sugar Street, p. 1039)

The translators, being dissatisfied with borrowing (the word "Waqf"), decided to add another TL phrase "mortmain trusts".

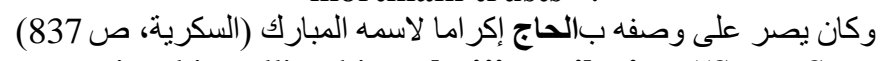

The old man persisted in calling him a hajji or pilgrim. ((Sugar Street, p. 1039)

Similarly, two words are used here: one being borrowed ("hajji"), the other a replacement "pilgrim". The translators have attempted to preserve the cultural impact of the religious word and have also used a TL word so that readers can understand the concept referred to by the religious word.The three strategies that are discussed above are applied to the translation of religious words only. The following examples deal with two strategies (i.e. explanation and substitution) that are applied to both religious words and expressions. Let us examine some examples of the explanation strategy:

$$
\begin{gathered}
\text { و عندما انتهى بها لتسبر الوثيد إلى جامع الحسين، خلع حذاءه ودخل وهو يتلو الفاتحة (السكرية، ص 878) } \\
\text { When his deliberate pace finally brought him to the mosque of al-Husayn, } \\
\text { he removed his shoes and entered, reciting the opening prayer of the } \\
\text { Qur'an. ((Sugar Street, p. 1124) }
\end{gathered}
$$

It should be noted that the religious word at the end of the SL sentence is not borrowed by the translators. Instead they opted for giving an explanation of the word.

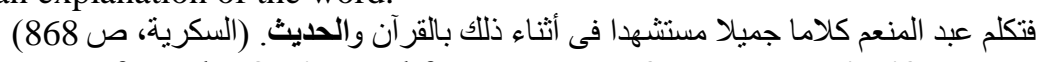

Citing passages from the Qur'an and from reports of the Prophet's life, Abd al-Man'im 
had offered an eloquent defense. ((Sugar Street, p. 1102)

The word "hadith" does not appear in the translation; the phrase that has replaced it is an explanation of the word. The examples given so far have involved the explanation strategy and they are all related to religious words. In the following examples, the explanation strategy is applied to the translation of religious expressions:

$$
\text { أن يكون الاختيار لوجه الله لا لو اسطة (السكرية، ص 889) }
$$

The selection should be based on merit, not influence. (Sugar Street, p. 1145)

The translators have explained the meaning of the expression "لوجه الهاله in such a way that they obliterated the religious overtone associated with the expression. In fact, the expression "لوجه " cannot mean the selection should be "on merit". They could have used such an expression as "do something for God", because the phrase "on merit" does not accurately reflect the intended meaning.

$$
\text { وسيأخذ الورقة صاحب القسمة والنصيب. (السكرية، ص Sitlet }
$$

Whoever is destined to receive the promotion will get it. (Sugar Street, p. 1145)

The translators have provided an explanation for the expression القسمة و النصيب, which has religious connotations. In fact, this expression is a collocation that is associated with the things that are predestined and cannot be prevented by human interference. Now let us turn to the substitution strategy as it is applied to the translation of religious words:

$$
\text { إن الدج أمنية قديمة (السكرية، ص }
$$

Pilgrimage is an old inspiration I've long nourished. (Sugar Street, p. 1281)

Note that a similar word (i.e. hajji) has already been shown to have been translated by using the strategy of borrowing plus substitution. Here the translators have used only the substitution strategy: they have used a TL word that does not have the same meaning as the SL word. The SL word means a journey to Mecca, whereas the TL word refers to a journey to a sacred place. The translators here, by using a domesticating strategy, have paid attention to the TL readers.

The substitution strategy can also be used with religious expressions, as in:

$$
\text { (تمث بصوت منخفض) الله يرحمها (السكرية، ص }
$$

In a hushed voice he added, God rest her soul. (Sugar Street, p. 1065)

Note that the Arabic expression " iاله يرحهم" is closely related to religion, for it is often used whenever the dead people are mentioned or remembered. People use this expression in order to beg for the mercy of God towards the dead people. Since this is a culture-specific expression, the translators opted for replacing it with a TL expression: "God rest her soul".

$$
\text { لا قدر الله ولا كان (السكرية، ص } 832 \text { (Sug) }
$$

God forbid! (Sugar Street, p. 1065)

The Arabic expression is produced if you are told that something bad is about to happen. By using this expression, one asks God to prevent it from happening. The expression used by the translators conveys the same meaning: hope that something will not happen. Such examples show that the translators do not hesitate to resort to a domesticating strategy.The following three strategies (calque, calque plus explanation, and omission) are attested only with the translation of religious expressions:

Calque is considered the most frequent strategy in the translation of religious words and expressions:

$$
\text { ربنا يهيكيك (السكرية 849) }
$$

May our Lord guide you. (Sugar Street, p. 1063)

$$
\text { ربنا الهادى (السكرية (S49) (S4) }
$$

Our Lord is the Guide. (Sugar Street, p. 1063)

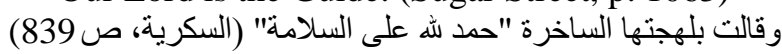

In her sarcastic voice, she said, "Praise God for your safe return" (Sugar Street, p. 1063)

All these examples involve a literal translation of the SL expression, but in an SL structure. This foreignizing strategy preserves the flavor of the SL culture. The Western reader, for example, can get an idea about how the people of the Islamic world are close to God during their everyday activities. The previous examples involve the strategy of calque without explanation on the part of translators. The following example shows that translators of religious expressions can use the strategy of calque plus explanation:

لم نقل إلا بسم الله الرحمن الرحيم ... لا تعترض. (السكرية، ص 845)

We've only recited the preliminary blessing: in the name of God, the

Compassionate, the merciful... Don't object. (Sugar Street, p. 1055)

Note that the part of the utterance that precedes the calque is an explanation. The reader may not have a full understanding without this explanation. This strategy caters for both the target reader and the source culture: the explanation is target reader-oriented, but calque is a foreignizing strategy.

The last strategy to be illustrated is omission. This strategy, like the strategy of claque plus explanation, is the least frequent in the list. In fact, only one example is attested:

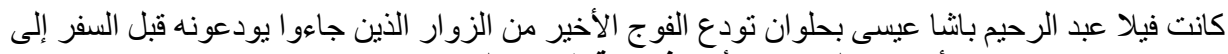

$$
\begin{aligned}
& \text { الأراضى الحجازية لأداء فريضة الحج. (السكرية، ص 954) }
\end{aligned}
$$


At Abd Al-Rahim Pasha Isa's villa in Hilwan, they were seeing out the last wave

Of the visitors who had come to say goodbye to him before his departure for the holy places of Hijaz. (Sugar Street, p. 1281).

Here the translators have avoided translating the religious phrase at the end of the sentence, "لأداء فريضة الحج". This foreignizing strategy is acceptable if omitting the translation of an expression does not impact the meaning. The meaning of the omitted expression in this example is already clear from the context, because readers can understand the purpose of visiting the holy places.

\section{Analysis and Discussion}

The target text (TT) contains both religious words and religious expressions. The overall number of these words and expressions is 93 . The religious expressions $(n=59)$, with the frequency count of $36.56 \%$, outnumber the religious words $(n=34)$, with $36.44 \%$. The translators have used several strategies to deal with these words and expressions. However, only two strategies are employed to render both religious words and religious expressions: explanation strategy and substitution strategy. Three strategies are used only with religious words (i.e. borrowing plus explanation, borrowing without explanation, and borrowing plus substitution) and three strategies (calque, calque plus explanation, and omission) are exclusively used with religious expressions. The following table shows how frequently each strategy recurs in the translation of the religious words and expressions:

Table 1: translation strategies of religious words and expressions

\begin{tabular}{|l|l|l|l|l|}
\hline strategylreligious elements & $\begin{array}{l}\text { Religious } \\
\text { word }\end{array}$ & $\begin{array}{l}\text { Religious } \\
\text { expression }\end{array}$ & tot & $\%$ \\
\hline Borrowing plus explanation & 10 & - & 10 & 10.7 \\
\hline Borrowing w/o explanation & 9 & - & 9 & 9.7 \\
\hline Borrowing plus substitution & 2 & - & 2 & 2.1 \\
\hline Explanation & 7 & 2 & 9 & 9.7 \\
\hline Substitution & 6 & 6 & 12 & 12.9 \\
\hline Calque & - & 49 & 49 & 52.7 \\
\hline Calque plus explanation & - & 1 & 1 & 1.1 \\
\hline Omission & - & 1 & 1 & 1.1 \\
\hline Total & 34 & 59 & 93 & 100 \\
\hline
\end{tabular}

Table (1) shows that only two strategies (i.e. explanation and substitution) are used with both religious words and religious expressions. The explanation strategy is used twice with religious expressions and seven times with religious words. The table also shows that there are exclusive strategies that are employed with religious words: borrowing plus explanation, which occurs 10 times, borrowing without explanation, which occurs 9 times and borrowing plus substitution occurring two times. The last three strategies (i.e. Calque, Calque plus explanation and omission) in the table are shown to be restricted to religious expressions. Here calque occurs 49 times, whereas each of the remaining two strategies occur once.

This table also indicates that the strategies do not have the same frequency in the overall translation of the words and expressions. Clearly, calque is the most frequent strategy with $52.7 \%$. It is followed by the substitution strategy $(12.9 \%)$, then comes borrowing plus explanation (10.7\%). Both borrowing without explanation and explanation strategies have the same frequency count $(9.7 \%)$, which are followed by borrowing plus substitution (2.1\%). The least frequent strategies are calque plus explanation and omission (with the frequency count of $1.1 \%$ each). It seems there is a weak negative correlation between the strategies used for religious words and those used for religious expressions $(r=-0.4)$ It is quite obvious that the translators of Sugar Street have employed both domesticating and foreignizing strategies for translating religious words or expressions (cf. table 2).

Table (2): foreignizing and domesticating strategies

\begin{tabular}{|c|c|c|c|c|}
\hline Major Strategy & Procedures & occurrences & Tot & $\%$ \\
\hline Foreignizing & $\begin{array}{l}\text { Calque } \\
\text { Borrowing without explanation }\end{array}$ & $\begin{array}{l}49 \\
9\end{array}$ & 58 & 62.37 \\
\hline Demosticating & $\begin{array}{l}\text { Substitution } \\
\text { Explanation } \\
\text { Omission }\end{array}$ & $\begin{array}{l}12 \\
9 \\
1\end{array}$ & 22 & 23.65 \\
\hline $\begin{array}{l}\text { foreignizing } \\
\text { domesticating }\end{array}$ & $\begin{array}{l}\text { Borrowing plus explanation } \\
\text { Calque plus explanation } \\
\text { Borrowing plus substitution }\end{array}$ & $\begin{array}{l}10 \\
1 \\
2\end{array}$ & 13 & 13.98 \\
\hline Total & & & 93 & 100 \\
\hline
\end{tabular}


As table (2) shows, the domesticating strategies are substitution, explanation, and omission. Both the substitution and explanation strategies are used to translate religious words and expressions. However, the omission strategy, which is not attested with the translation of religious words, is the least frequent strategy in the list. These three strategies aim at facilitating the task of the target language reader and enabling the translators to avoid flooding $\mathrm{him} / \mathrm{her}$ with foreign culture-specific elements.

As for the foreignizing strategies, they include Calque and borrowing without explanation. Calque is the most frequent strategy and borrowing without explanation occupies the fourth rank in the hierarchy of strategies. Both of them aim at reviving the SL cultural values. The translators who use these strategy close the gap between cultures and promote mutual respect, cooperation and understanding. The translators of Sugar Street have also used strategies that are both domesticating and foreignizing: borrowing plus explanation, borrowing plus substitution and calque plus explanation. The first part of each strategy indicates that it is foreignizing: borrowing involves the direct use of an SL word or expression. Likewise, calque requires a literal translation of SL expressions. However, the second part (i.e. explanation), which is TL reader-oriented, aims at facilitating the task of the reader.

Note that table (2) shows that the foreignizing strategy is the most frequent of all, with the frequency count of $62.7 \%$. The domesticating strategy comes next with the frequency of $23.65 \%$, whereas the third type is the least frequent with $13.98 \%$. Given that the foreignizing strategies are more frequent than the domesticating strategies in the translation of religious words and expressions, it can be safely said that the translators of Naguib Mahfouz's novel Sugar Street have adopted foreignizing as a basic strategy. This is probably due to the fact that one of the translators is a native speaker of the SL, whereas the other is a native speaker of the TL. It is also clear that no translation can be completely based on one strategy with the exclusion of the others. The same translator has to depend on both foreignizing and domesticating strategies. The new globalization has already narrowed the gap between cultures and the people of different countries and cultures have been sharing cultural elements such as clothing, food and drinks, sports etc. Only religious elements remain impervious to change or manipulation.

\section{Conclusion}

This study has proven that the translation of a novel can be based on different strategies. No translator can depend on only one strategy. The translators of Sugar Street have relied on three major strategies: foreignizing strategy, domesticating strategy and a third strategy that is a mixture of these two. It has also been indicated that the foreignizing strategy turned to be the most frequent strategy in the translation of religious words and expressions. The translators probably could not find equivalents for these words or expressions. The examination of the data has shown that when translators found an adequate equivalent for a word or expression, they had no hesitation in using it. The foreignizing strategy is dominant in the translation of this novel because religion is one of the cornerstones of the novel and religion is not very often susceptible to change.

\section{References}

Abdel-Hafiz, A. S. (2004). Cultural elements in the translation of Mahfooz's The Beginning and the End and Palace of Desire, TRANS. Internet-Zeitschrift für Kulturwissenschaften 15

.http://www.inst.at/trans/15Nr/07_2/abdelhafiz15.htm

Al-Debyan, Q. (2008). Strategies for translating Arabic cultural markers into English: A foreignizing approach. Ph.D dissertation, University of Arkansas.

Baawaidhan, A. (2016). Applying foreignization and domestication in translating Arabic Dialectical Expressions into English, International Journal of Linguistics 8 (4), 197-217.

Baker, M. (1992). In other words: A course book on translation. London and New York: Routledge.

Bolinger, D \& Sears, D. (1968). Aspects of language. New York: Harcourt Brace Jovanovich

El-Enany, R. (1988). Religion in the novels of Naguib Mahfouz, Bulletin (British Society for Middle Eastern Studies15 (1/2), pp. 21-27. https://www.jstor.org/stable/195213

Gambier, Y. (2007) Doubts and directions in translation studies, The Netherlands: John Benjamins.

Hutchins, W., \& Saman, A. (1992). Sugar Street. London: Doubleday.

Khammyseh, D. (2015). The Problems in translating Islamic expressions in religious occasions, Journal of Education and Practice 6 (35), 103-109.

Mahfouz, N. (1957). Al-Sukkariyya. Cairo: Daar El-Shrouq.

Mehawesh, M. I. \& Sadeq, A. (2014). Islamic Religious expressions in the translation of Naguib Mahfouz Novel "The Beginning and the End, Research on Humanities and Socia Sciences 4 (12), 7-18.

Munday, J. (2001). Introducing translation studies: Theories and applications. London and New York: Routledge

Obeidat, A. M. \& Mahadi, T.S. (2019). Collocation translation errors from Arabic to English: A case study of Naguib Mahfouz's novel “Awlad Haratina”, International Journal of Humanities, Philosophy, and Language 21 (7),129-138. 
Al Rabadi, R. (2012) A moment of truth in translating proper names in Naguib Mahfouz' Trilogy from Arabic into English, Cross-Cultural Communication 8 (6), 43-47.

Schäffner, C. \& Wiesemann, U. (2001). Annotated texts for translation: English-German. Functionalist approaches illustrated. Frankfurt: Multilingual Matters.translation

Shehab, E. (2005). The translatability of terms of address in Najib Mahfouz's Ziqaq Al-Midaq into English, AlNajah Journal Research 19 (1), 309-321.

Siregar, R. (2016). Translation procedures analysis: English - Indonesian motivational book, Journal Of Humanities And Social Science 21 (5), 51-57

Vanuti, L. (1995). The Translator's invisibility: A history of translation. London and New York: Routledge.

Vanuti, L. (1997). The American tradition, in Baker, M (Ed.), The Routledge encyclopedia of translation, (pp. 305315), London and New York: Routledge. 